\title{
Spectrum of VP1 region genetic variants in the foot-and-mouth disease virus serotype $O$ populations derived from infected cattle tongue epithelium
}

\author{
L. N. SARANGI ${ }^{1}$, J. K. MOHAPATRA ${ }^{1}$, S. SUBRAMANIAM ${ }^{1}$, L. K. PANDEY ${ }^{1}$, B. DAS ${ }^{1}$, A. SANYAL ${ }^{1}$, \\ J. MISRI ${ }^{2}$, B. PATTNAIK ${ }^{*}$
}

${ }^{1}$ Project Directorate on Foot and Mouth Disease, Mukteswar, Nainital-263138 Uttarakhand, India; ${ }^{2}$ Indian Council of Agricultural Research, Krishi Bhavan, New Delhi 110 001, India

Received January 29, 2015; revised March 2015; accepted July 28, 2015

\begin{abstract}
Summary. - RNA virus population exists as a complex distribution of non-identical but closely related sequences known as viral quasispecies. Variant strains are selected from this quasispecies population in response to changing environment. The quasispecies dynamics of a virus existing within an infected host differs from that in a cell culture-adapted population. This study was carried out to explore the genetic variations present in the VP1 coding region of the foot-and-mouth disease (FMD) virus serotype O derived directly from infected cattle tongue epithelium. Molecular clonal populations of two serotype $\mathrm{O}$ strains belonging to lineages Ind2001 (IND 30/2011) and PanAsia2 (IND 5/2011) were sequenced at VP1 coding region. For IND 30/2011, 19 clones were sequenced and analysis showed variations at 12 nucleotide positions (nt) resulting in 8 amino acid (aa) replacements. Similarly, for IND 5/2011 virus, 18 clones were sequenced, of which six showed nt variations leading to 3 aa replacements. Most of the variable positions mapped to the surface-exposed loops and some of them were found in the neutralizing antigenic sites (position 81, 149, 169, 186 and 202 of IND 30/2011 and 141 of IND 5/2011), which potentially could be beneficial in rapid adaptive evolution of the virus by giving rise to antigenic variants to overcome neutralizing antibodies. These findings encourage further research into the landscape of the viral quasispecies population in vivo and its implication for viral ecology.
\end{abstract}

Keywords: foot-and-mouth disease virus; VP1 region; variants in vivo

\section{Introduction}

Foot-and-mouth disease (FMD), primarily a disease of cattle, buffalo and pigs, is one of the most feared animal diseases owing to nearly $100 \%$ morbidity, rapid spread, severe decrease in livestock productivity, mortality in young animals and obstacles to the international trade in livestock and livestock products (Rowlands, 2003). The disease is caused by FMD virus, a prototype member of the genus Aphthovirus in the family Picornaviridae (Racaniello, 2001). The virus exists as seven antigenically and genetically distinct serotypes [(O, A, C, Asial and Southern African Territories

*Corresponding author: E-mail: pattnaikb@gmail.com; phone: +91-5942-286004.

Abbreviations: FMD = foot-and-mouth disease
(SAT)-1, 2, 3)]. Each serotype contains numerous lineages and strains showing variable degree of antigenic diversity (Domingo et al., 2003). The virus genome is a single stranded positive-sense RNA molecule of $\sim 8.5 \mathrm{kbp}$ size that encodes a single poplyprotein, which is protelytically cleaved into four structural and eight nonstructural proteins. Among the four structural proteins, the hypervariable VP1 protein is located around the icosahedral 5-fold axes and it contributes the most to the accessible surface of the virus. It houses integrin receptor-binding motifs and neutralizing antigenic sites, thus evolves under immune pressure (Kitson et al., 1990; Mateu, 1995; Domingo et al., 2003; Jackson et al., 2003). Therefore, sequence analysis of VP1 region has been widely applied in epidemiological investigations to characterize field strains of FMD viruses. Due to the absence of proofreading activity of viral RNA-dependent RNA polymerase, the progeny virus population is expected to consist of numerous closely related 
mutant genomes existing in equilibrium around a theoretical consensus sequence. This complex and dynamic distribution of non-identical but related sequences is termed as viral quasispecies (Domingo et al., 1978; Eigen and Schuster, 1979; Holland et al., 1992). From this quasispecies population, antigenically divergent strains could be selected either in the presence or absence of immune pressure (Borrego et al., 1993; Domingo et al., 1993; Holguin et al., 1997; Sarangi et al., 2013), which might compromise vaccine efficacy (Feigelstock et al., 1996).

The genetic variations in FMD virus have been extensively investigated in the cell culture-derived biological clonal populations giving emphasis on frequency of mutation, rate of evolution of capsid sequence and antigenic diversification with or without immune pressure (Borrego et al., 1993; Domingo et al., 1993; Holguin et al., 1997; Arias et al., 2001; Airaksinen et al., 2003). The genetic composition of the quasispecies swarm generated in cell culture system is thought to be different from that of the virus replicating inside a host as the selection pressures and constraints shaping the course of evolution are different and many of the minor variants in vivo could be lost during propagation in vitro (Baranowski et al., 2003; Domingo et al., 2006; Carrillo et al., 2007). Moreover, during propagation in cell culture additional mutations, which were nonexistent in the in vivo population, could arise. Therefore, the present study was undertaken to identify the variant genomes existing in vivo by molecular cloning and sequencing of the VP1 coding region amplified directly from infected cattle tongue epithelium.

\section{Materials and Methods}

Viruses. In this study, two serotype O viruses (IND 5/2011 and IND 30/2011) belonging to PanAsia-2 and Ind2001 lineage, respectively, were used in the form of clinical tongue epithelial samples derived from infected cattle in FMD outbreaks during the year 2011.

Determination of lineage and consensus sequence. For lineage determination, the RNA was extracted from tongue epithelium suspensions using RNeasy Mini Kit (QIAGEN). The reverse transcription of the viral RNA was carried out using Superscript ${ }^{\mathrm{TM}}$ III RNAse $\mathrm{H}$ reverse transcriptase (Invitrogen) employing NK61 reverse primer (complementary to position 3630-3649 of 2B region). The full-length VP1 coding region was amplified by PCR with NK61-ARS4 primers (1301 base pair) (ARS4 primer is complementary to nucleotides 2349-2369 of VP3 region) using Platinum Taq High Fidelity enzyme (Invitrogen) to minimize mis-incorporations (Knowles and Samuel, 1995). The consensus sequences for both viruses were determined from the purified PCR product directly on ABI 3130 genetic analyzer (Applied Biosystems) using NK61 and ARS4 primers (Knowles and Samuel, 1995).
Analysis of quasispecies composition. To study the quasispecies composition at VP1 coding region, the PCR amplicons were ligated to pGEM-T-Easy vector (Promega). The competent Escherichia coli JM109 cells (Promega) were transformed with the ligation mixture and plated on Luria Bertani-ampicillin agar plates. The recombinant colonies were screened by insert specific PCR and restriction enzyme digestion with EcoRI (Promega). 19 positive clones of IND 30/2011 and 18 clones of IND 5/2011 virus were selected and plasmids were extracted. The recombinant plasmids were sequenced on ABI 3130 genetic analyzer (Applied Biosystems). Nucleotide sequences were processed using ABI sequence analysis v5.3.1 software, and contigs were assembled using EditSeq programme of Lasergene core suite 10 (DNASTAR, Inc., USA). The VP1 region sequences (639 nucleotides) were aligned using clustal W algorithm (Thompson et al., 1994) available in MEGA 5.05 program (Tamura et al., 2011). In order to rule out the incorporation of error during sequencing step, the clones showing amino acid (aa) difference from the consensus sequence generated directly from PCR amplicons were re-sequenced.

\section{Results}

To study the within-host genetic variation at VP1 coding region of serotype $\mathrm{O}$ virus, molecular cloning technique was used. For IND 30/2011 (Ind2001 lineage) virus, 19 positive plasmid clones were sequenced and analysis of the results showed nucleotide variations at 12 different positions as compared to the consensus sequence derived directly from the PCR amplicon. When the deduced aa sequences were aligned, 8 variations were found. A total of 11 clones showed sequence exactly identical to the consensus sequence (derived from PCR products before cloning), whereas 5 clones showed one nucleotide substitution and 3 clones showed two nucleotide substitutions (Table 1). However, none of the nucleotide variations occurred in more than one clone. Nucleotide variations were observed at positions 33, 76, 166, 241, 369, 394, 446, 507, 543, 556, 606 and 636, resulting in aa variation at positions 26,56 , $81,132,149,169,186$ and 202 (Table 1). Similarly, for IND 5/ 2011 (PanAsia lineage) virus, 18 clones were sequenced. 13 clones were found to be identical with the consensus sequence, while 5 clones showed one nucleotide difference and one clone showed two nucleotide differences. Out of the 6 nucleotide changes, 3 were non-synonymous mutations resulting in aa substitutions. Nucleotide substitution was observed at positions 157, 328, 342, 345, 421 and 450, and aa variations were seen at positions 53, 110 and 141. Most of the aa variations mapped to the surface-exposed loops and some of them were found in the neutralizing antigenic sites (Table 1). 
Table 1. Nucleotide and amino acid variations observed in the VP1 coding region of different molecular clones of serotype O FMD virus compared to the majority sequence derived directly from PCR amplicon generated from tongue epithelium

\begin{tabular}{|c|c|c|c|c|c|c|}
\hline Virus & Clone No. & $\begin{array}{c}\text { Nucleotide } \\
\text { position }\end{array}$ & $\begin{array}{c}\text { Nucleotide } \\
\text { change }\end{array}$ & $\begin{array}{l}\text { Amino acid } \\
\text { position }\end{array}$ & $\begin{array}{l}\text { Amino acid } \\
\text { change }\end{array}$ & Structural element \\
\hline \multirow[t]{12}{*}{ IND 30/2011 } & 1 & 33 & $\mathrm{G} \rightarrow \mathrm{A}$ & - & - & - \\
\hline & 9 & 76 & $A \rightarrow G$ & 26 & $\mathrm{R} \rightarrow \mathrm{G}$ & N-terminus \\
\hline & 17 & 166 & $A \rightarrow G$ & 56 & $\mathrm{~T} \rightarrow \mathrm{A}$ & $\beta C-\beta D$ loop \\
\hline & 19 & 241 & $A \rightarrow G$ & 81 & $\mathbf{K} \rightarrow \mathbf{E}$ & $\beta \mathrm{D}$ strand \\
\hline & 5 & 369 & $\mathrm{C} \rightarrow \mathrm{T}$ & - & - & - \\
\hline & 7 & 394 & $\mathrm{G} \rightarrow \mathrm{A}$ & 132 & $\mathrm{G} \rightarrow \mathrm{R}$ & $\beta \mathrm{G}-\beta \mathrm{H}$ loop \\
\hline & 4 & 446 & $\mathrm{~A} \rightarrow \mathrm{T}$ & 149 & $\mathrm{Q} \rightarrow \mathrm{L}$ & $\beta G-\beta H$ loop \\
\hline & 4 & 507 & $\mathrm{G} \rightarrow \mathrm{C}$ & 169 & $\mathrm{~K} \rightarrow \mathrm{N}$ & $\beta$ H- $\beta$ I loop \\
\hline & 5 & 543 & $A \rightarrow G$ & - & - & - \\
\hline & 19 & 556 & $\mathrm{~T} \rightarrow \mathrm{C}$ & 186 & $\mathbf{Y} \rightarrow \mathbf{H}$ & C-terminus \\
\hline & 13 & 606 & $A \rightarrow C$ & 202 & $\mathrm{~K} \rightarrow \mathrm{N}$ & C-terminus \\
\hline & 13 & 636 & $\mathrm{C} \rightarrow \mathrm{T}$ & - & - & - \\
\hline \multirow[t]{6}{*}{ IND 05/2011 } & 1 & 157 & $\mathrm{C} \rightarrow \mathrm{A}$ & 53 & $\mathrm{~L} \rightarrow \mathrm{M}$ & $\beta \mathrm{C}-\beta \mathrm{D}$ loop \\
\hline & 2 & 328 & $\mathrm{G} \rightarrow \mathrm{A}$ & 110 & $\mathrm{~A} \rightarrow \mathrm{T}$ & $\beta$ F- $\beta$ G loop \\
\hline & 1 & 342 & $A \rightarrow G$ & - & - & - \\
\hline & 5 & 345 & $\mathrm{~T} \rightarrow \mathrm{A}$ & - & - & - \\
\hline & 16 & 421 & $\mathrm{G} \rightarrow \mathrm{T}$ & 141 & $\mathbf{V} \rightarrow \mathbf{L}$ & $\beta G-\beta$ H loop \\
\hline & 10 & 450 & $\mathrm{G} \rightarrow \mathrm{T}$ & - & - & - \\
\hline
\end{tabular}

Antigenically critical residues are shown in bold face.

\section{Discussion}

Natural populations of FMD virus from a single outbreak have been shown to be heterogeneous both genetically and antigenically and, moreover, an isolate obtained from an individual animal comprises more than one nucleotide sequence (Wright et al., 2011; Morelli et al., 2013). High mutation rate of FMD virus led to the proposal that FMD virus natural populations do exist as quasispecies (Domingo et al., 1992). FMD virus strains are normally genetically described by a single sequence that represents the consensus of what is thought to be an underlying swarm of closely related genetic variants. Nevertheless, the consensus could change with time and space depending on the frequency of distribution of the variants in the quasispecies cloud. Conventional sequencing has provided insights into the genetic variation within population (Carrillo et al., 2007). This is achieved through sequence analysis of either the biological clones (virus from individual plaques formed on the cell monolayer) or molecular clones (PCR products cloned in $E$. coli). Recently, with the advance of next generation sequencing (deep sequencing), the polymorphic structures of viral populations have been dissected with greater resolution. The technique has been used to compare viral population within two bovine epithelial samples from a single animal, to study intra-sample sequence diversity during serial transmission in bovine hosts and to detect site-specific polymorphism in the virus population generated after in vitro passages under antibody pressure (Wright et al., 2011; Morelli et al., 2013; Pandey et al., 2014).

Characterization of the mutant spectra of virus quasispecies is finding increasing application in the understanding of virus pathogenesis and evolution of viruses (Forns et al., 1999; Arias et al., 2001; Domingo et al., 2001). Arias et al. (2001) studied the mutant spectrum of FMD virus by nucleotide sequencing of three regions (internal ribosomal entry site, region between 2 AUG initiation codon in L and VP1 coding region) from 70 biological and 70 molecular clones. The results obtained by both methods were statistically indistinguishable with regard to the distribution of mutations among the three genomic regions analysed, type of mutation observed, mutational hot spot and mutation frequencies. Subsequently, molecular cloning technique has been used to study viral quasispecies of Asia 1 virus (Li et al., 2011) and serotype $O$ virus (Cottam et al., 2009) and for many human viruses, e.g. hepatitis viruses, caliciviruses, enteric coronaviruses and papillomaviruses, which either do not grow in cell culture or grow poorly (Esteban et al., 1999; Forns et al., 1999; Flint et al., 2000; Domingo et al., 2001).

In this study, representative serotype $\mathrm{O}$ strains belonging to two predominant lineages circulating in India (Ind2001 and PanAsia) were analyzed in order to decipher the mutant distribution in the infected host-derived population of virus (Subramaniam et al., 2013). Although it is possible that vari- 
ations are present in the entire genome in the quasispecies population, only those variants that differ from the consensus in the capsid coding region could be considered important in the context of selection and emergence of antigenically divergent strains under immune pressure. Since VP1 protein is the most exposed part of the capsid surface, contains immunodominant antigenic sites and can tolerate extensive aa replacements, this preliminary investigation reports variations observed in the VP1 coding region (Domingo et al., 1990; Mateu, 1995; Martin et al., 1998).

Nucleotide sequencing of 19 positive clones of IND $30 / 2011$ showed nucleotide variation at 12 different positions, which in turn resulted in 8 aa variations. Similarly for IND 05/2011 sequence, of 18 positive clones showed 6 nucleotide variations resulting in changes at 3 aa positions (Table 1). None of the nucleotide variations happened to be present in more than one clone, suggesting site-specific polymorphism to exist at a very low frequency in the population. Furthermore, none of the polymorphic loci was found to be shared between the two strains, thereby implying existence of a signature demographic structure for each strain of the virus. A total of only 3 transversions out of 12 substitutions were seen in case of IND 30/2011 clones, while a relatively higher proportion of transversions (4 out of 6 substitutions) were observed for IND 05/2011. Therefore, no specific bias in favor of either transitions or transversions in the population of variants could be proved. Most of the aa variations mapped to the exposed loops on the capsid surface, which are considered to be less constrained structural elements (Table 1). Notably, three of the 11 aa variations were found to be located on the hypervariable $\beta \mathrm{G}-\beta \mathrm{H}$ loop of VP1.

Out of the positions showing aa variations, position 141 occurs in the $\beta \mathrm{G}-\beta \mathrm{H}$ loop of VP1 upstream of the integrinbinding 'RGD' motif and position 202 at the carboxy terminal of VP1, which are known to be constituents of antigenic site 1 in serotype O FMD virus (Kitson et al., 1990; Mateu, 1995). Likewise, position 149 occurs in the $\beta \mathrm{G}-\beta \mathrm{H}$ loop of VP1 and has been reported to be the antigenic site 5 of serotype O FMD virus (Crowther et al., 1993; Aktas and Samuel, 2000). Similarly, aa 81, 169 and 186 are known to be part of minor antigenic sites in serotype A virus (Thomas et al., 1988; Baxt et al., 1989) and may be of antigenic importance in serotype $\mathrm{O}$ as well. Codons 56 and 81 are predicted to be under positive selection pressure in serotype $\mathrm{O}$ virus and therefore could be experiencing adaptive evolution (Lewis-Rogers et al., 2008). Alignment of VP1 sequence of Indian field isolates revealed variability at aa positions $26,56,81,110$ and 141 , thereby supporting existence of genetic polymorphism at those positions in the naturally evolving virus populations as well. The presence of a higher number of clones with sequences identical to the consensus sequence provides support for the dominance of the consensus sequence in the population at a given timepoint. More importantly, the presence of minor sequences/ antigenic variants in the quasispecies spectrum supports the possibility of their selection and likely dominance under hostile circumstances such as pre-existing host immunity. Further, such variant population demography suggests the intrinsic ability of the virus to mutate and rapidly adapt to changing environments. The findings of this study do encourage further research into genome-wide variant distribution, which may provide insights into virus evolution at population level in vivo.

Acknowledgements. The authors are thankful to Indian Council of Agricultural Research for providing necessary facilities to carry out this work. The first author is thankful to ICAR for providing senior research fellowship during his doctoral degree.

\section{References}

Airaksinen A, Pariente N, Menendez-Arias L, Domingo E (2003): Curing of foot-and mouth disease virus from persistently infected cells by ribavirin involves enhanced mutagenesis. Virology 311, 339-349. http://dx.doi.org/10.1016/S00426822(03)00144-2

Aktas S, Samuel AR (2000): Identification of antigenic epitopes on the foot and mouth disease virus isolate O1/Manisa/ Turkey/69 using monoclonal antibodies. Rev. Sci. Tech. Off. Int. Epiz. 19, 744-753.

Arias A, Lazaro E, Escarmis C, Domingo E (2001): Molecular intermediates of fitness gain of an RNA virus: characterization of a mutant spectrum by biological and molecular cloning. J. Gen. Virol. 8, 1049-1060. http://dx.doi. org/10.1099/0022-1317-82-5-1049

Baranowski E, Molina N, Nú-ez JI, Sobrino F, Sáiz M (2003): Recovery of infectious foot-and-mouth disease virus from suckling mice after direct inoculation with in vitrotranscribed RNA. J. Virol. 77, 11290-11295. http://dx.doi. org/10.1128/JVI.77.20.11290-11295.2003

Baxt B, Vakharia V, Moore DM, Franke AJ, Morgan DO (1989): Analysis of neutralising antigenic sites on the surface of type A12 foot-and-mouth disease virus. J. Virol. 63, 2143-2151.

Borrego B, Novella IS, Andreu D, Giralt E, Domingo E (1993): Distinct repertoire of antigenic variants of foot-and-mouth disease virus in the presence and absence of immune selection. J. Virol. 67, 6071-6079.

Carrillo C, Lu Z, Borca MV, Vagnozzi A, Kutish GF, Rock DL (2007): Genetic and phenotypic variation of foot-andmouth disease virus during serial passages in a natural host. J. Virol. 81, 11341-11351. http://dx.doi.org/10.1128/ JVI.00930-07

Cottam EM, King DP, Wilson A, Paton DJ, Haydon DT (2009): Analysis of Foot-and-mouth disease virus nucleotide sequence variation within naturally infected epithelium. Virus Res. 140, 199-204. http://dx.doi.org/10.1016/j. virusres.2008.10.012

Crowther JR, Farias S, Carpenter WC, Samuel AR (1993): Identification of a fifth neutralizable site on type $\mathrm{O}$ foot-and-mouth 
disease virus following characterization of single and quintuple monoclonal antibody escape mutants. J. Gen. Virol. 74, 1547-1553. http://dx.doi.org/10.1099/00221317-74-8-1547

Domingo E, Biebricher C, Eigen M, Holland JJ (2001): Quasispecies and RNA Virus Evolution: Principles and Consequences. Austin, TX: Landes Bioscience.

Domingo E, Díez J, Martínez MA, Hernández J, Holguín A, Borrego B, Mateu MG (1993): New observations on antigenic diversification of RNA viruses. Antigenic variation is not dependent on immune selection. J. Gen. Virol. 74, 2039-2045. http://dx.doi.org/10.1099/0022-1317-7410-2039

Domingo E, Escarmis C, Baronowski E, Ruiz-Jarabo CM, Carrillo E, Nunez JI, Sobrino F (2003): Evolution of foot-andmouth disease virus. Virus Res. 91, 47-63. http://dx.doi. org/10.1016/S0168-1702(02)00259-9

Domingo E, Escarmis C, Martinez MA, Martinez-Salas E, Mateu MG (1992): Foot-and-mouth disease virus populations are quasispecies. Curr. Top. Microbiol. Immunol. 176, 33-47. http://dx.doi.org/10.1007/978-3-642-7701113

Domingo E, Mateu MG, Martínez MA, Dopazo J, Moya A, Sobrino F (1990): Genetic variability and antigenic diversity of foot-and-mouth disease virus. In Kurstak E, Marusyk RG, Murphy SA, Van-Regenmortel MHV (Eds): Applied Virology Research, Vol. 2, Virus Variation and Epidemiology. Plenum Publishing Corp., New York, pp. 233-266. http://dx.doi.org/10.1007/978-1-4757-9271-3 15

Domingo E, Sabo D, Taniguchi T, Weissmann C (1978): Nucleotide sequence heterogeneity of an RNA phage population. Cell 13, 735-744. http://dx.doi.org/10.1016/0092-8674(78) $90223-4$

Domingo E, Martin V, Perales C, Grande-Pérez A, García-Arriaza J, Arias A (2006): Viruses as Quasispecies: Biological Implications. Curr. Top. Microbiol. Immunol. 299, 51-82. http://dx.doi.org/10.1007/3-540-26397-7 3

Eigen M, Schuster P (1979): The Hypercycle. A Principle of Natural Self-Organization. Springer-Verlag, Berlin.

Esteban JI, Martell M, Carman WF, Gomez, J (1999): The impact of rapid evolution of the hepatitis viruses. In Domingo E, Webster RG and Holland JJ (Eds): Origin and Evolution of Viruses. San Diego, Academic Press, pp. 345-376. http:// dx.doi.org/10.1016/b978-012220360-2/50014-3

Feigelstock DA, Mateu MG, Valero ML, Andreu D, Domingo E, Palma EL (1996): Emerging foot-and-mouth disease virus variants with antigenically critical amino acid substitutions predicted by model studies using reference viruses. Vaccine 14, 97-102. http://dx.doi.org/10.1016/0264-410$\underline{\mathrm{X}(95) 00180-9}$

Flint SJ, Enquist LW, Krug RM, Racaniello VR, Skalka AM (2000): Principles of Virology: Molecular Biology, Pathogenesis and Control. 1st ed. Washington, DC: American Society for Microbiology (ASM) press.

Forns X, Purcell RH, Bukh J (1999): Quasispecies in viral persistence and pathogenesis of hepatitis $\mathrm{C}$ virus. Trends Microbiol. 7, 402-410. http://dx.doi.org/10.1016/S0966$\underline{842 X(99) 01590-5}$
Holguin A, Hernandez J, Martinez MA, Mateu MG, Domingo E (1997): Differential restrictions on antigenic variation among antigenic sites of foot-and-mouth disease virus in the absence of antibody selection. J. Gen. Virol. 78, 601609. http://dx.doi.org/10.1099/0022-1317-78-3-601

Holland JJ, De La Torre JC, Steinhauer DA (1992): RNA virus populations as quasi-species. Curr. Top. Microbiol. Immunol. 176, 1-20. http://dx.doi.org/10.1007/978-3-642-77011-1_1

Jackson T, King AMQ, Stuart DI, Fry E (2003): Structure and receptor binding. Virus Res. 91, 33-46. http://dx.doi. org/10.1016/S0168-1702(02)00258-7

Kitson JDA, McCahon D, Belsham GJ (1990): Sequence analysis of monoclonal antibody resistant mutants type $\mathrm{O}$ foot-andmouth disease virus: Evidence for the involvement of the three surface exposed capsid proteins in four antigenic site. Virology 179, 26-34. http://dx.doi.org/10.1016/0042$\underline{6822(90) 90269-W}$

Knowles NJ, Samuel AR (1995): Polymerase chain reaction amplification and cycle sequencing of the 1D (VP1) gene of foot-and-mouth disease viruses. Report of the Session of the Research Group of the Standing Technical Committee of the European Commission for the Control of Foot-andMouth Disease held jointly with the FMD Sub-group of the Scientific Veterinary Committee of the Commission of the European Community, Mödling, Vienna, Austria, Appendix 8, pp. 45-53.

Lewis-Rogers N, McClellan DA, Crandall KA (2008): The evolution of foot-and-mouth disease virus: Impacts of recombination and selection. Infect. Genet. Evol. 8, 78-98. http:// dx.doi.org/10.1016/j.meegid.2008.07.009

Li P, Lu Z, Bao H, Li D, King DP, Sun P, Bai X, Cao W, Gubbins S, Chen Y, Xie B, Guo J, Yin H, Liu Z (2011): In-vitro and in-vivo phenotype of type Asia 1 foot-and-mouth disease viruses utilizing two non-RGD receptor recognition sites. BMC Microbiol. 11, 154. http://dx.doi.org/10.1186/14712180-11-154

Martin MJ, Nunez JI, Sobrino F, Dopazo J (1998): A procedure for detecting selection in highly variable viral genomes: evidence of positive selection in antigenic regions of capsid protein VP1 of foot-and-mouth disease virus. J. Virol. Methods 74, 215-221. http://dx.doi.org/10.1016/ $\underline{\text { S0166-0934(98)00088-3 }}$

Mateu MG (1995): Antibody recognition of picornaviruses and escape from neutralization: a structural view. Virus Res. 38, 1-24. http://dx.doi.org/10.1016/0168-1702(95)00048-U

Morelli MJ, Wright CF, Knowles NJ, Juleff N, Paton DJ, King DP, Haydon DT (2013): Evolution of foot-and-mouth disease virus intra-sample sequence diversity during serial transmission in bovine hosts. Vet. Res. 44, 12. http://dx.doi. org/10.1186/1297-9716-44-12

Pandey LK, Mohapatra JK, Subramaniam S, Sanyal A, Pande V, Pattnaik B (2014): Evolution of serotype A foot-andmouth disease virus capsid under neutralizing antibody pressure in vitro. Virus Res. 181, 72-76. http://dx.doi. org/10.1016/j.virusres.2014.01.009

Racaniello VR (2001): Picornaviridae: the viruses and their replication. In Knipe DM, Howley PM, Griffin DE, Lamb RA, Martin MA, Roizman B, Straus SE (Eds): Fields Virology, 
vol. 1, 4th ed. Lippincott Williams \& Wilkins, Philadelphia, PA, pp. 685-722.

Rowlands DJ (2003): Preface. Virus Res. 91, 1. http://dx.doi org/10.1016/S0168-1702(02)00264-2

Sarangi LN, Mohapatra JK, Subramaniam S, Sanyal A, Pattnaik B (2013): Antigenic site variation in foot-and-mouth disease virus serotype $O$ grown under vaccinal serum antibodies in vitro. Virus Res. 176, 273-279. http://dx.doi. org/10.1016/j.virusres.2013.07.003

Subramaniam S, Pattnaik B, Sanyal A, Mohapatra JK, Pawar SS, Sharma GK, Das B, Dash BB (2013): Status of footand-mouth disease in India. Transbound. Emerg. Dis. 60, 197-203. http://dx.doi.org/10.1111/j.1865-1682 2012.01332.x

Tamura K, Peterson D, Peterson N, Stecher G, Nei M, Kumar S (2011): MEGA5:molecular evolutionary genetics analysis using maximum likelihood, evolutionary distance, and maximum parsimony methods. Mol. Bio. Evol. 28, 2731-2739. http://dx.doi.org/10.1093/molbev/msr121

Thomas AAM, Woortmeijer RJ, Puijk W, Barteling SJ (1988): Antigenic sites on foot-and-mouth disease virus type A10. J. Virol. 62, 2782-2789.

Thompson JD, Higgins DG, Gibson TJ (1994): CLUSTAL W: improving the sensitivity of progressive multiple sequence alignment through sequence weighting, positionspecific gap penalties and weight matrix choice. Nucleic Acids Res. 22, 4673-4680. http://dx.doi.org/10.1093/ nar/22.22.4673

Wright CF, Morelli MJ, Thébaud G, Knowles NJ, Herzyk P, Paton DJ, Haydon DT, King DP (2011): Beyond the consensus: dissecting within-host viral population diversity of foot-and-mouth disease virus by using next-generation genome sequencing. J. Virol. 85, 2266-2275. http://dx.doi. org/10.1128/JVI.01396-10 